\section{Military Technical College Kobry El-Kobbah, Cairo, Egypt}

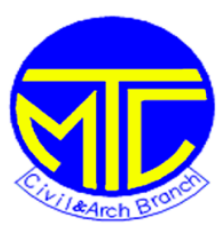

\title{
The Influence of Using Vertical Solar PV in Rationalization of Energy Consumption in Residential Buildings
}

Dr. Mohamed Salah Gharib
Dr. Esraa Ahmed Aboushal

\begin{abstract}
$\underline{\text { Abstract }}$
As a result of repetitive terroristic attacks in Rafah city, the Egyptian government had to evacuate Rafah to eradicate terrorism. It is planned to build New Rafah city at a distance from the borders.

So if we are going to build a new settlement why not to build it right?

The aim of this research is to build new Rafah city convenient to their occupants by fulfilling both psychological and physical comfort.

This paper demonstrates a number of climatic and energy characteristics of building in the desert of the hot arid region. It presents proposed techniques for using vertical solar Photovoltaic Panels (PV) that installed on building facades. Designer can find out suitability for putting PVs installation in the façade surfaces of buildings using Google Earth imagery and ArcGIS software for spatial and attribute data of buildings in this defined urban study area. The approach entails modeling the solar irradiance characteristics of the site by fitting the probability distributions of the solar irradiance data measured during the day. Thereafter; it could be estimated the solar radiations factor according to analysis of different designs of PV modules. The module with the highest average factor is identified as the best suited module for the given site.
\end{abstract}

\section{$\underline{\text { Kev words }}$}

Photovoltaic (PV); Vertical Solar PV, 3D Modeling, Visualization., Geographical Information System (GIS).

\footnotetext{
1-Dr. Mohamed Salah Gharib, Architectural Department, The Higher Canadian Institute for Engineering at $6^{\text {th }}$ October, (CIC), EGYPT E-mail: mohds69@gmail.com Cell Phone :(+2) 01222640690

2-Dr. Esraa Ahmed Aboushal, Architectural Department, High Institute of Engineering and Technology, (BHI), EGYPT

E-mail: esraaaboushal1 @ gmail.com. Cell Phone :(+2) 01289931406
} 


\section{Introduction}

Due to the fact that, roughly $50 \%$ of the energy consumed is used in the construction and operation of buildings, which account for $81 \%$ of the total Egypt electricity expenditures, architects play a major role in the reduction of energy consumption. [1]

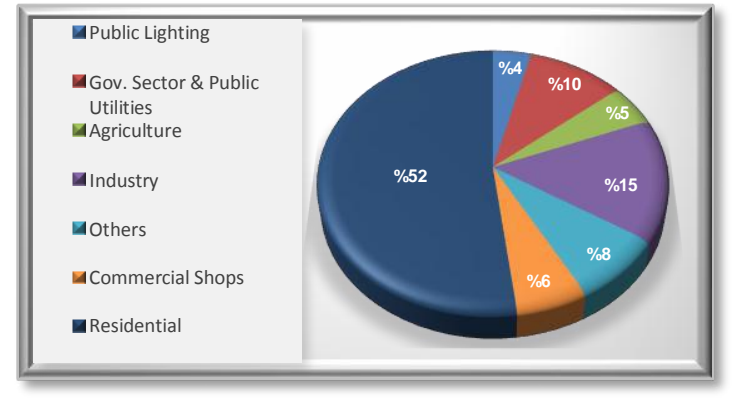

Figure- 1: Total Distribution of Energy Consumption in Egypt for 2014/2015. [2]

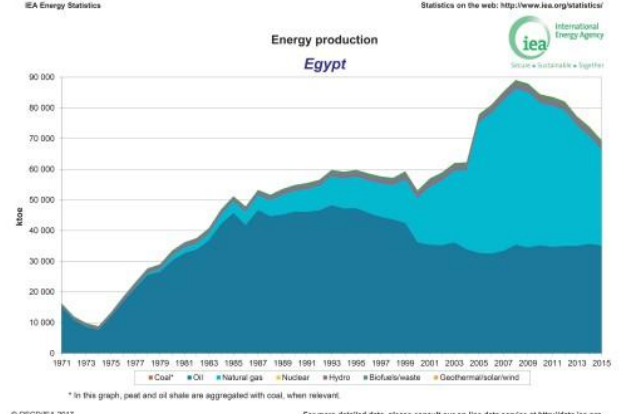

Figure- 2: Energy Production in Egypt for 2014/2015. [3]

Using vertical solar PV installed on building facades can potentially produce clean electricity to meet the energy demand of the buildings and also provides protection from weather.

So the research presents the importance of studying the vertical solar PV for the architectural façade that is one of advanced technology aspect for contributing in optimal use of solar energy. It changes dynamically rather than being static or fixed, allowing movement to occur on a building's façades. This helps to create a building's envelope that is an active system rather than just a container. Technological façade can be used to manage light, air, energy, and even information. They can act to reduce solar gain as well as allowing the passage of fresh air into the building, helping to alter the interior environment. The moving elements of the façade can be programmed to respond to climatic or other environmental factors, time, levels, type of occupancy and so on to improve performance and efficiency using vertical solar PVs. This combination is done with advances in sensors, materials and building management technology. So; designers are increasingly able to consider technological façade components as design solutions. [4] \& [5]

This could be done using Geographical Information System (GIS) technology in analyzing automated spatial data of vertical solar PV potential and designing for an urban area in Rafah. GIS database would have records of each house for energy generation via connecting algorithms with theoretical formulas. Every house has its number, area size and selected area for panel installation. The energy generated through the vertical PV system is between $1.5 \mathrm{GW}$ and 5GW annually. [6]

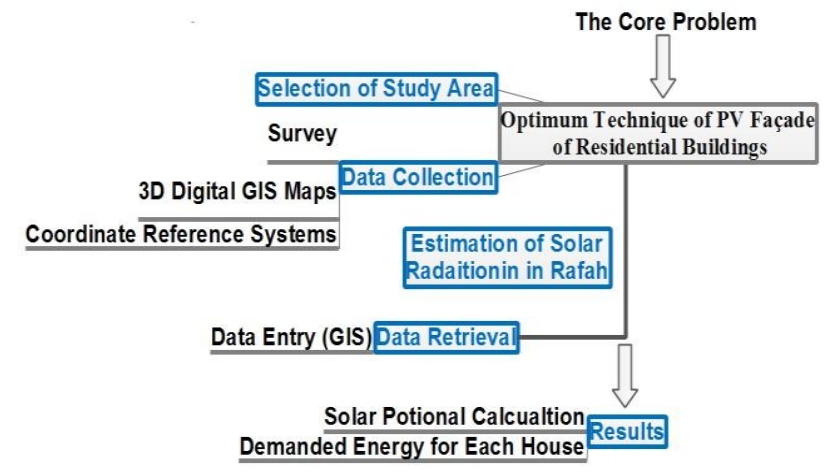

Figure- 3: Flow Chart of Current Study [7] 


\section{Criteria of Selected Area (New Rafah)}

\section{Site Selection}

The study area is Rafah which locates in Sinai Peninsula. It is about 22 Acres that could be located in Google Earth software ${ }^{\mathrm{TM}}$ with a geo-referencing parameters $\left(31^{\circ} 17^{\prime} \mathrm{O}^{\prime \prime} \mathrm{N}, 34^{\circ} 14^{\prime} \mathrm{O}^{\prime \prime} \mathrm{E}\right)$. The study area was chosen as it has unique design; it is bordered to the north by main road of Al Arish-Rafah. Rafah pertains various topographic variation and high suitability for vertical solar PV that could be installed on residential building facades. [7]

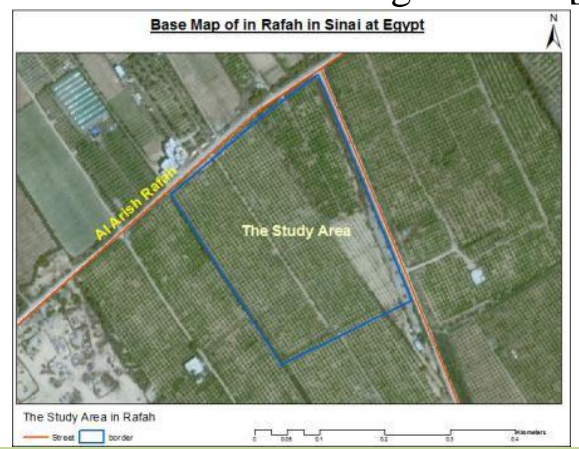

Figure- 4: Location of Study Area at Rafah in Arc Map Software According to Geo-Referencing in Google Earth. [7]

\section{The Climate Criteria}

Köppen-Geiger climate classification system classifies its climate as hot semi-arid .The pattern of weather and climate in Sinai are largely dictated by its position between the vast landmasses of Africa and Asia. Neither the Mediterranean nor the Red Sea significantly ameliorates the extremes of continentally inherited from its large land neighbors. The aridity dominates this environment. Rafah is characterized by hot dry summers and mild rainy winters.

\section{Solar Radiation}

The annual radiation for the entire region averages is more than $500 \mathrm{cal} / \mathrm{cm}^{2} /$ day. A high percentage of Rafah's daylight hours are cloud free time averages $74 \%$.

\section{Atmospheric Temperature}

The temperature during summer can be around $30{ }^{\circ} \mathrm{C}$ during daytime, and rarely 'exceeds $35^{\circ} \mathrm{C}$ due to the influence of the sea. Winters range from mild to cool during the day and chilly during the night and temperatures dip below $6{ }^{\circ} \mathrm{C}$. [8]

Table- 1: Climate data for Rafah, North Sinai. [8]

\begin{tabular}{|c|c|c|c|c|c|c|c|c|c|c|c|c|c|}
\hline Month & Jan & Feb & Mar & Apr & May & Jun & Jul & Aug & Sep & Oct & Nov & Dec & Year \\
\hline Average high ${ }^{\circ} \mathrm{C}$ & 17.2 & 18 & 20.3 & 22.9 & 25.8 & 28.2 & 29.6 & 30.5 & 29 & 27.4 & 23.7 & 19.3 & 24.33 \\
\hline Daily mean ${ }^{\circ} \mathbf{C}$ & 12.7 & 13.5 & 15.4 & 18 & 20.8 & 23.5 & 25.2 & 25.9 & 24.5 & 22.4 & 18.6 & 14.7 & 19.6 \\
\hline Average low ${ }^{\circ} \mathrm{C}$ & 8.2 & 9 & 10.6 & 13.2 & 15.9 & 18.8 & 20.8 & 21.4 & 20 & 17.4 & 13.5 & 10.1 & 14.91 \\
\hline $\begin{array}{c}\text { Av. precipitation } \\
\mathrm{mm}\end{array}$ & 49 & 37 & 28 & 6 & 4 & 0 & 0 & 0 & 0 & 8 & 39 & 54 & 225 \\
\hline
\end{tabular}



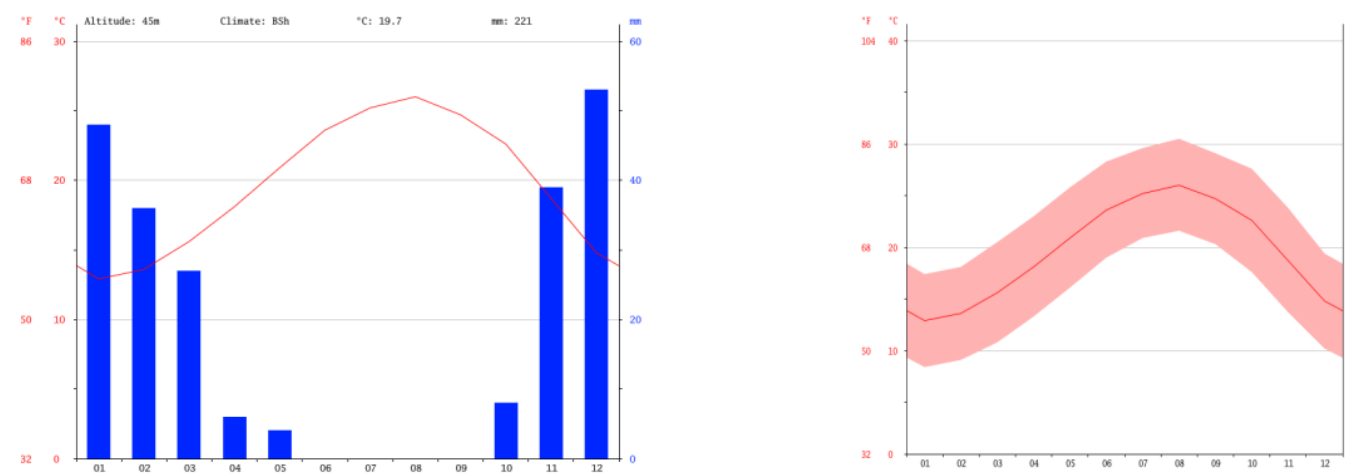

Figure-5\&6: Temperature Graph Rafah. [8]

\subsubsection{Wind}

The prevailing winds of Sinai are from the north, however, mountain barriers and deep wadi channels often modify these winds locally. The general air flow from the Mediterranean is the source of nearly all precipitation, the bulk of which falls in winter. With the onset of spring there is an increased chance for strong winds, still predominantly from the north. But the south winds are the most dreaded. These tend to be abnormally hot and dry and accompanied by hazy atmosphere. Such a wind is, known as the "Khamasin" for the fifty days in which it is oppressive and frequently damages vegetation. Severe sand and dust storms often accompany the Khamasin.

\section{Precipitation}

There is a difference of $53 \mathrm{~mm}$ of precipitation between the driest and wettest months. The driest month is June, with $0 \mathrm{~mm}$ of rain. In December, the precipitation reaches its peak, with an average of $53 \mathrm{~mm}$.

Rainfall is average with sometimes hail, sleet and rarely snow takes place. [8]

\section{Social Housing Building Model}

A model for social residence has been chosen to the basic unit for a modern new settlement. Residential building has area $360 \mathrm{~m}^{2} /$ building. Each floor consists of (4) units.

It was taken into consideration during designing that each building is multi-floor (ground, first), (ground, first, second), (ground, first, second, third).

Residential loads are estimated by $30-50 \mathrm{VA} / \mathrm{m}^{2}$ for moderate residential building loads.

$$
\mathrm{P}_{\mathrm{tot}}=40 \times 360 \times 3=43200 \mathrm{KVA} .[9]
$$

The residential unit is composed of:

\begin{tabular}{cc|}
\hline Room & Area \\
\hline Living \& Dining room & $21.4 \mathrm{~m}^{2}$ \\
\hline Master Bedroom & $12 \mathrm{~m}^{2}$ \\
\hline Bedroom & $10.8 \mathrm{~m}^{2}$ \\
\hline Bedroom & $9.5 \mathrm{~m}^{2}$ \\
\hline Bathroom & $2.6 \mathrm{~m}^{2}$ \\
\hline Kitchen & $7.4 \mathrm{~m}^{2}$ \\
\hline
\end{tabular}



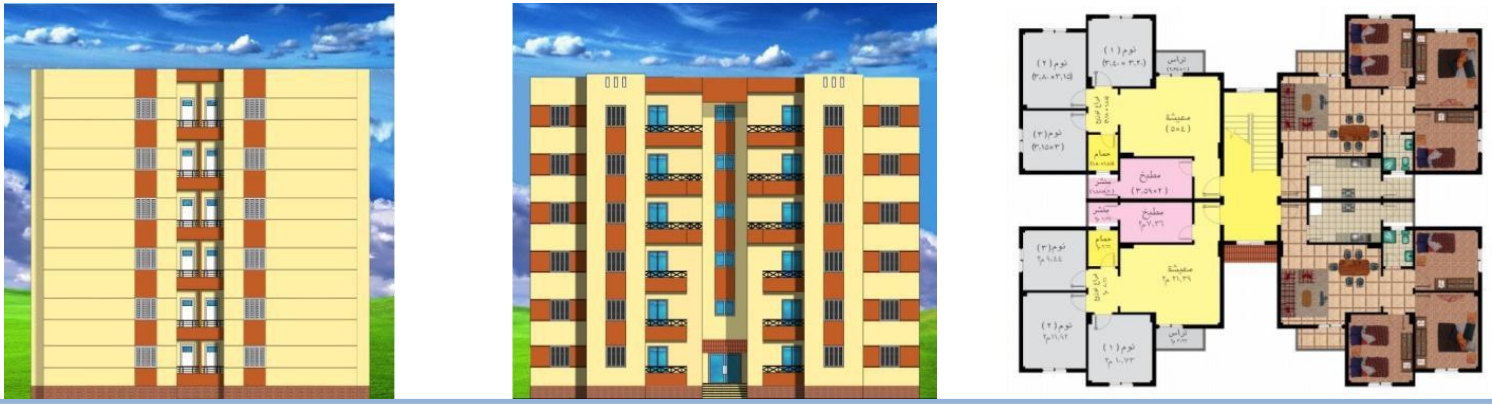

Figure-7: The Residential Model [7]

\section{Building Skin Parameters}

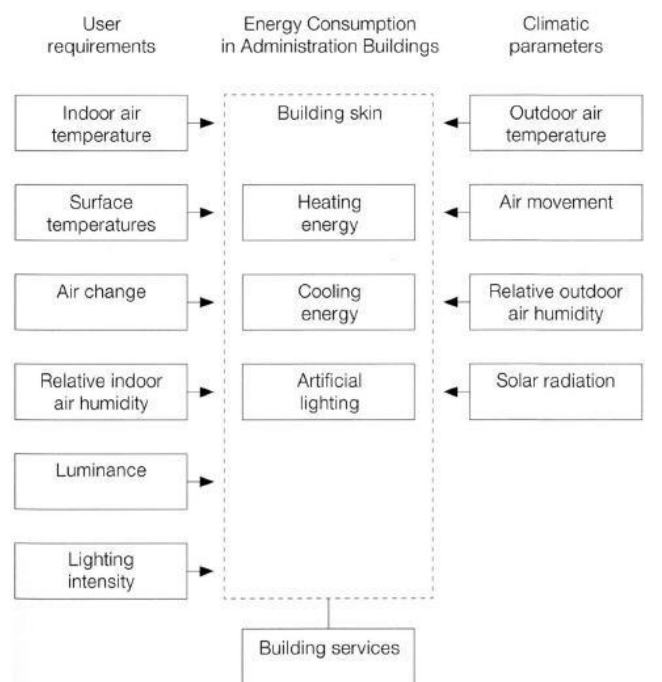

Figure-8: Building Skin Parameters for Proposing Vertical Façade of Solar PV System. [7]

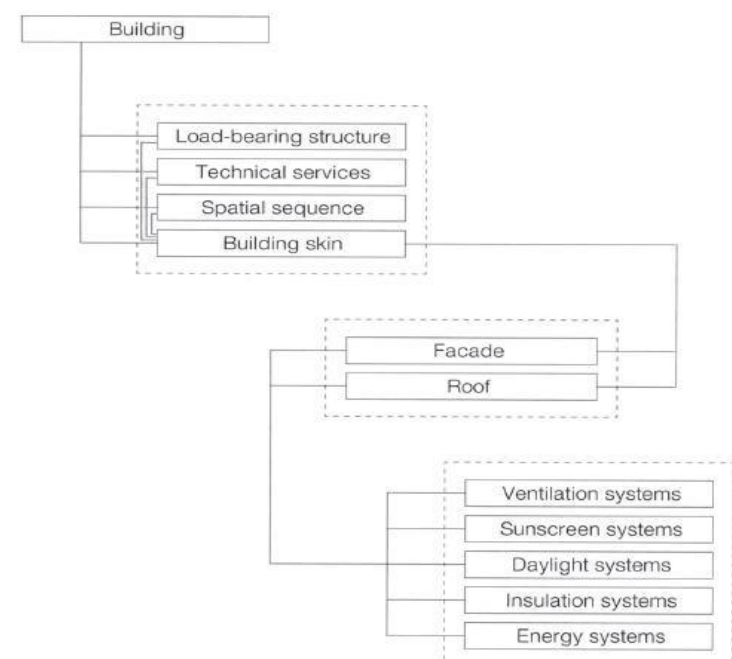

Figure-9: Overall Building System for Proposing Vertical Façade of Solar PV System. [7]

\section{Building Orientation}

The buildings were oriented such that the openings are in east-west axis to decrease energy consumption by use of daylight.

The best four vertical façade orientations for PV application in climatic condition of Rafah are east, west, southeast and southwest as these façades received the highest incident irradiance. [6]

Table-2: The Simulation Results of the Building Orientation with Vertical Solar PV. [7]

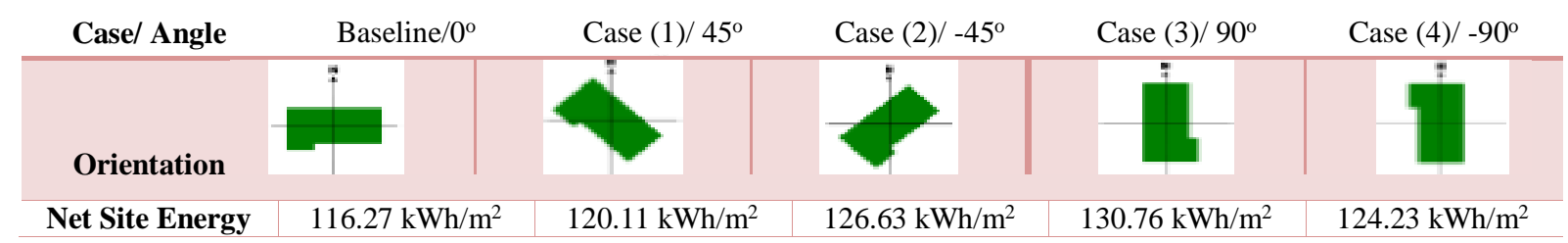




\section{Vertical Solar PV}

The PV specifications assist builders in designing and constructing homes equipped with a set of features that make the installation of solar energy systems after the completion of the home's construction easier and less expensive. The specifications are based on best management practices and balanced with practical issues of cost.[10]

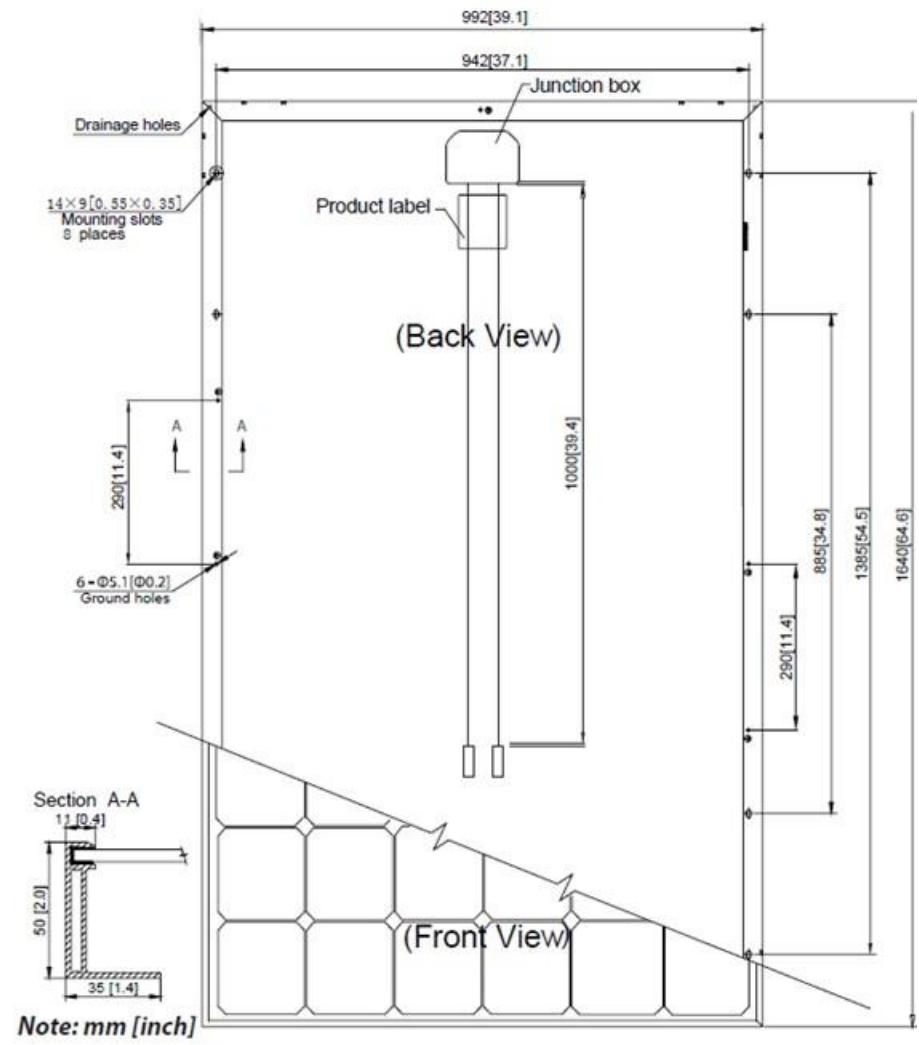

Figure-10: Detailed design of used Vertical Solar PV in the study area at Unit: mm.[10]

\section{Vertical Solar PV (Performance)}

\section{High module conversion efficiency}

Module efficiency up to $15.4 \%$ achieved through advanced cell technology and manufacturing capabilities.

2. Extended wind load tests

Module certified to withstand extreme wind (3800 Pascal).

3. Self-cleaning \& anti-reflective

Higher module efficiency from anti-reflective, hydrophobic layer with higher light absorption and minimal surface dust.

4. Excellent weak light performance

Excellent performance under low light.

5. Suntech current sorting process

System output maximized by reducing mismatch losses up to $2 \%$ with modules sorted $\&$ packaged by amperage. [11] 


\section{Vertical Solar PV (Operating Condition)}

Accordingly, the specifications of vertical solar PV are calculated and showing that the most preferable module belong to Max.

\section{Electrical Characteristics}

At Standard Test Conditions (STC): irradiance $1000 \mathrm{~W} / \mathrm{m}^{2}$, module temperature $25{ }^{\circ} \mathrm{C}$, $\mathrm{AM}=1.5$. power measurement uncertainty is within $+/-3 \%$

Table-3: The Specifications of Vertical Solar PV module used in the case study. [10]

STC

\begin{tabular}{l|c}
\hline Optimum Operating Voltage (Vmp) & ST.7 V \\
\hline Optimum Operating Current (Imp) & $8.15 \mathrm{~A}$ \\
\hline Open Circuit Voltage (Voc) & $37.4 \mathrm{~V}$ \\
\hline Short Circuit Current (Isc) & $8.63 \mathrm{~A}$ \\
\hline Watt.hour /Day & $124800.0 \mathrm{~W}$ \\
\hline Operating Module Temperature & $-40{ }^{\circ} \mathrm{C}$ to $+85^{\circ} \mathrm{C}$ \\
\hline Maximum System Voltage & $1000 \mathrm{~V} \mathrm{DC}$ (IEC) \\
\hline Maximum Series Fuse Rating & $20 \mathrm{~A}$ \\
\hline Power Tolerance & $0 /+5 \%$ \\
\hline Running hours & 8 \\
\hline Select Size of Solar Panel & $1.6 \mathrm{~m} 2$ \\
\hline Number of String for Solar Panel & 346 \\
\hline Total Watt of Each Solar Panel String & $250 \mathrm{~W}$ \\
\hline Total Watts of Solar Panels & $86500 \mathrm{~W}$ \\
\hline
\end{tabular}

\section{Temperature Characteristics}

Table-4: The Temperature Characteristics of Vertical Solar PV. [10]

Nominal Operating Cell Temperature (NOCT)

Temperature Coefficient of Pmax

Temperature Coefficient of Voc

Temperature Coefficient of Isc
$45 \pm 2^{\circ} \mathrm{C}$

$-0.45 \% /{ }^{\circ} \mathrm{C}$

$-0.34 \% /{ }^{\circ} \mathrm{C}$

$0.050 \% /{ }^{\circ} \mathrm{C}$

\section{Mechanical Characteristics}

Table-5: The Mechanical Characteristics of Vertical Solar PV. [10]

Solar Cell

No. of Cells

Dimensions

Weight

Front Glass

Frame

Output Cables
Monocrystalline silicon $156 \times 156 \mathrm{~mm}$ $60(6 \times 10)$ $1640 \times 992 \times 50 \mathrm{~mm}$

$$
19.1 \mathrm{kgs}
$$

$3.2 \mathrm{~mm}$ tempered glass

Anodized aluminium alloy

TUV (2Pfg1169:2007), UL 4703, UL44

$4.0 \mathrm{~mm}^{2}$, symmetrical lengths (-) $1000 \mathrm{~mm}$ and (+) $1000 \mathrm{~mm}$ 
Current-Voltage \& Power-Voltage Curve (250S-20)

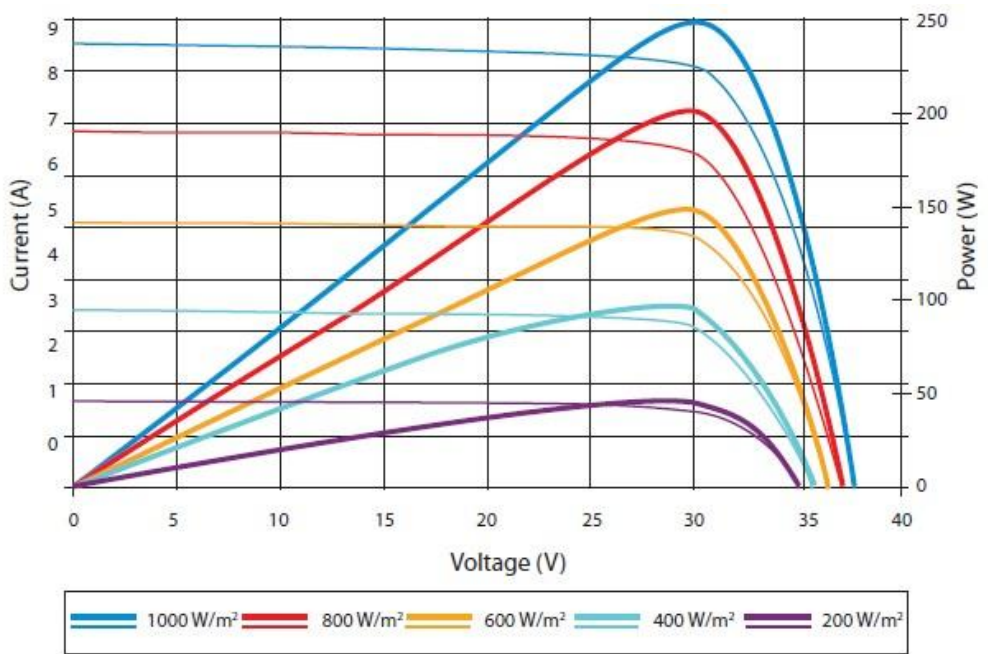

Figure-11: Excellent performance under weak light conditions: at an irradiation intensity of $200 \mathrm{~W} / \mathrm{m}^{2},\left(\mathrm{AM} 1.5,25^{\circ} \mathrm{C}\right)$, $95.5 \%$ or higher of the STC efficiency $\left(1000 \mathrm{~W} / \mathrm{m}^{2}\right)$ is achieved.[1]

\section{Suggested Building Model with Vertical PV.}

In the case study, the vertical PVs are furnished over the south and west facades. The dimensional drawings illustrate the size of the two facades (which is given by $414 \mathrm{~m}^{2}$ and $342 \mathrm{~m}^{2}$, respectively).

Grid-Tie application has been selected for the case study which so-called PV on-grid system The proposed system is Parallel connected PV modules to an on-gird system. [12]

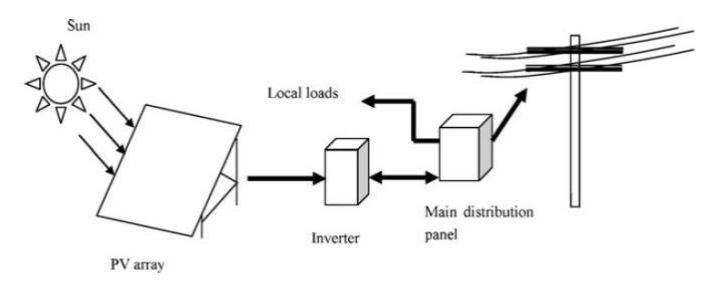

Figure-12: On-Grid PV system with no storage.[12]

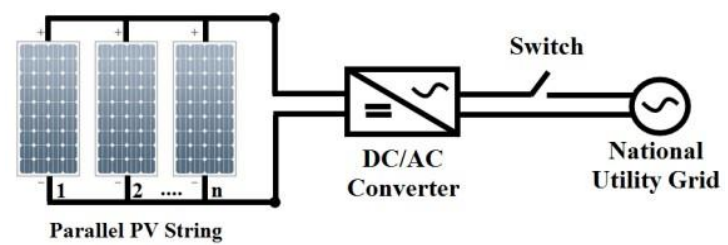

Figure-13: Parallel connected PV modules to an on-gird system.[13]

\section{Digitizing Database}

Spatial data was prepared with the help of Google Earth Map and ground surveys while attribute information for the proposed buildings and estimated electricity database is assigned by the researcher's studies and Rafah Electric Supply Company's website for the individual meteorological and irradiation data files for Rafah in Sinai at Egypt which recorded for every hour per day.

Three layers were created for database in the ArcGIS software. These layers consist of boundary of the study area, main road and raster layer for the calculation of solar energy potential. Google Earth satellite imagery was used as a base map to digitize area for vertical solar PV installation on façade of residential buildings. 
South, south east and south west directions are best for PV installation. All buildings in the study area have flat surfaces at their façade which receives direct solar radiations without any shaded area.

In the study area, it could be estimated the solar radiation potential related to spatial relationship to other data using solar radiation spatial analyst tool in ArcScene software through the energy value $\left[\mathrm{kWh} / \mathrm{m}^{2} \mathrm{a}\right]$ for a test area according to spatial and semantic properties.
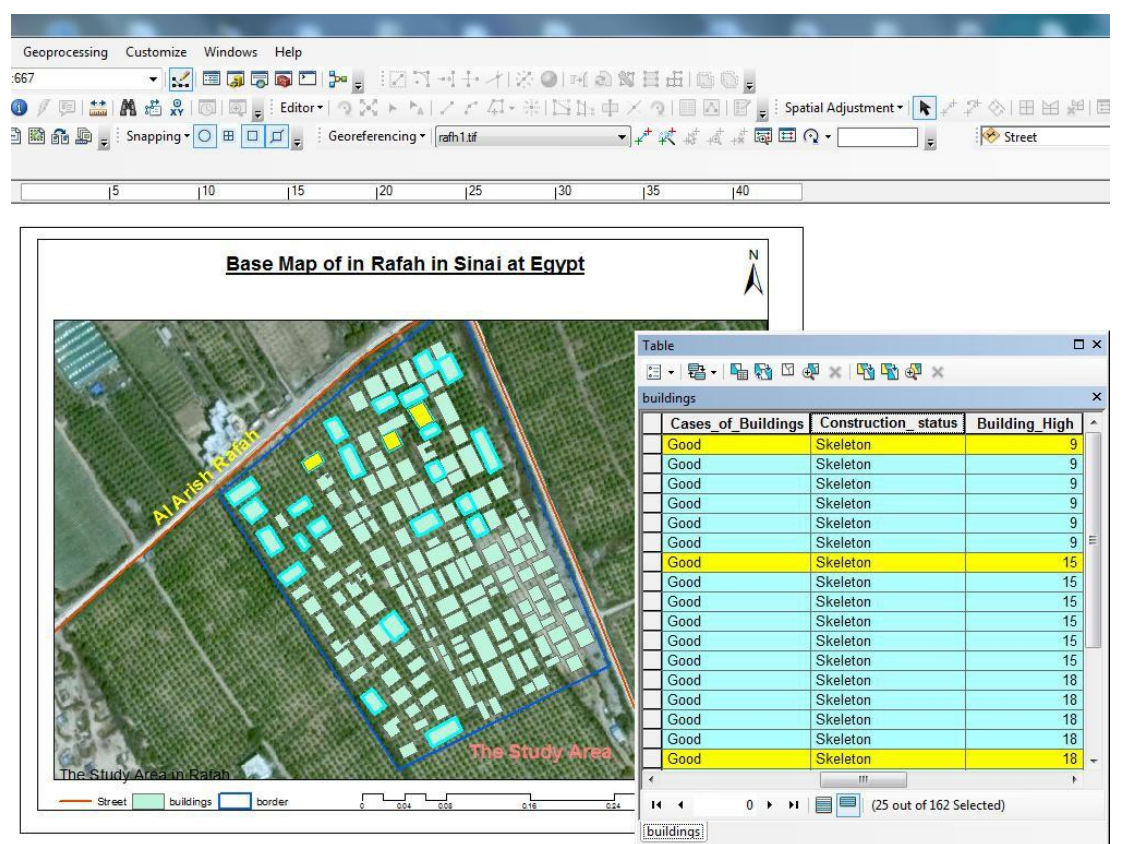

Figure-14: Visualizing the Georeferenced Buildings Model with all Attribute Data Table for all 2D Elements in a Base Map of Rafah in ArcMap Software According to WGS1984.[7]

\section{Calculating The Solar Radiation}

Calculating the solar radiation is a configuration of ArcGIS that can be evaluated for assessing if buildings have potential for solar panel installation. Visualize vertical solar PV for the architectural facade of buildings in a 3D scene and evaluate total solar radiation per selected surface area of the buildings.

\section{Steps of The Calculation}

The implementation of solar radiation consumption depends on geo-processing criteria $\underline{a s}$ follows:

a. The calculation of every building location factor according to Aspect (orientation), the surface azimuth angle, the building height, thematic hull surfaces that have been integrated and based on building typologies.

b. The inserting of the solar radiation capacity factor according to the record of each house, its area selected for PV installation, its monthly, yearly electric energy generation. 


\section{Research Outcome}

Consequently; the results for every building are written in new generic attributes in a geodatabase within the ArcScene file considering that all the building's façades have the same elevation. This calculation is using solar radiation spatial analyst tool in ArcScene software through the energy value $\left[\mathrm{kWh} / \mathrm{m}^{2} \mathrm{a}\right]$ for a test area according to spatial and semantic properties.

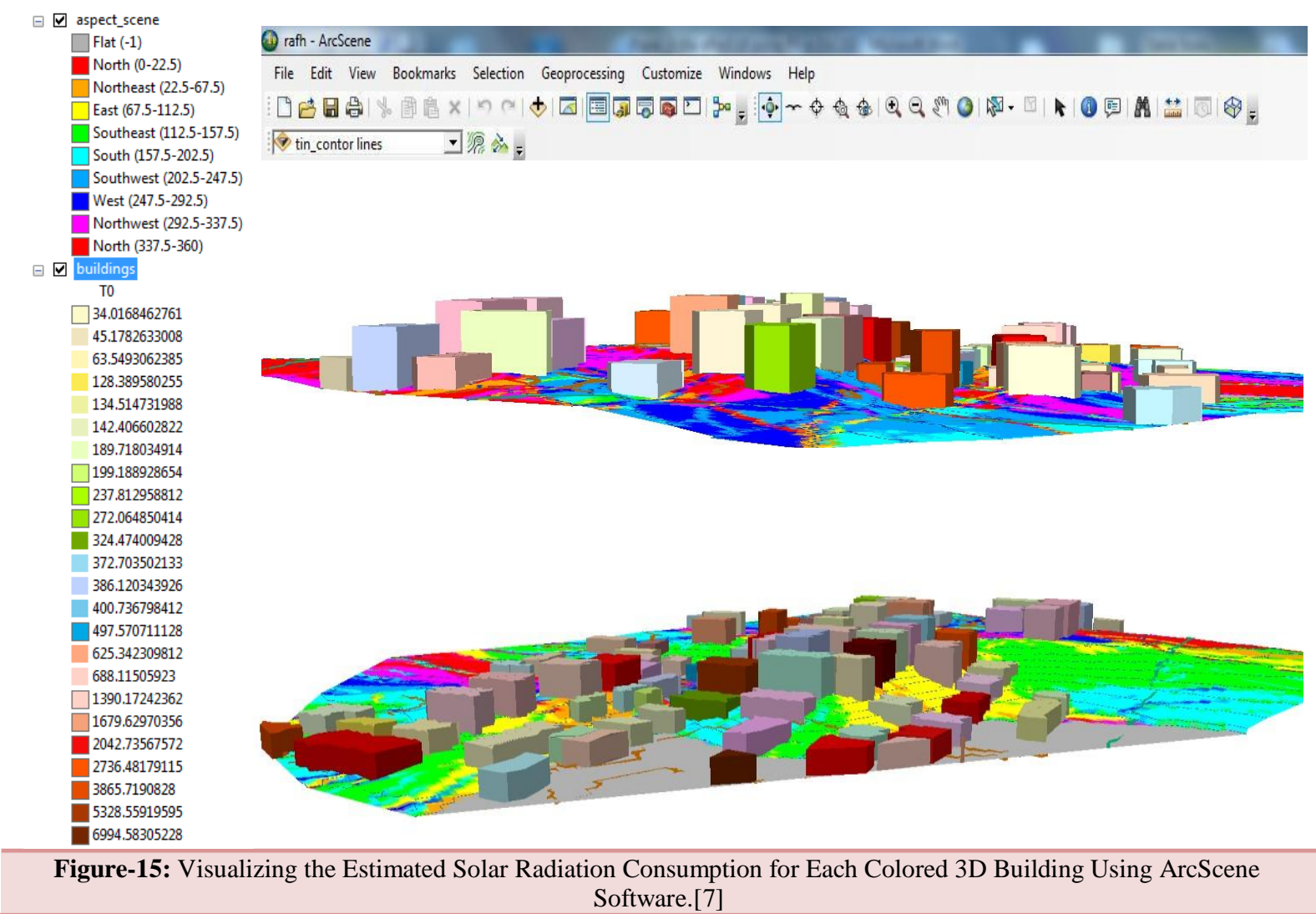

In this study, using of vertical solar PV for the architectural façade has been analyzed in accordance with the calculation of solar radiation for optimum selection façade. So; it could be reached to the following points:

a. Building process of orientation of every building according to the projection system in 3D GIS model.

b. Using the probability of optimistic location of PV panels in the building's façade by evaluating the optimum selection for a typical site related to estimated solar radiation consumption for each colored 3D building using ArcScene software.

c. The optimum selection of PV panels depends on many other parameters, such as the PV Specifications as the Max. system voltage, Max. series fuse rating, Operating temperature range, Max. static load, front (e.g., snow and wind), Max. static load, back (e.g., wind), Max. hailstone impact (diameter / velocity).

d. Accordingly, the Max. system voltage factor has been obtained at different seasons facilitating the selection of the best suited vertical solar PV module at the specified site location that is based on how much power could be extracted from the PV modules at any desired time to supplement the power demand.

e. The results obtained from the distribution of vertical PVs have revealed that the south 
facade yield more efficient output power towards the on-gird systems in relevant to the west façade.

\section{Conclusion}

The study presents the ability to define the using of vertical solar PV for the architectural façade of buildings model at a case study model of Rafah in Sinai at Egypt. This model is considered as generated simulation model according to spatial system as well. This could be done by modeling the solar radiation characteristics of the site to estimate it and measured at specific geographical location using ArcGIS software through 3D spatial database. The proposed PV panels can be used in local level with the available possibilities in Egypt that are effectually applicable in improving the exchange of urban data that is based on unified geodatabase. Also; the proposed PV panels is capable of improving the interoperability with urban data during various tasks such as designing and collaborating urban planning for developing any urban area according to proper characteristics of planning. Using vertical solar PV for the architectural façade by estimating the solar radiation would be very helpful for solving the lack of energy in every residential building. This study would benefit different stakeholders such as; expert urban planners and different local authorities. Indeed, the proposed model can be tested and evaluated before implementing it in the real site to achieve the most appropriate results for execute more sustainable buildings to save energy consumption. Moreover; reduction of $38.2 \%$ or more ratio in the total site energy consumption can be achieved on changing the design decisions and parameters; building orientation, location of windows which have a direct influence on energy use, and indoor environment. Energy simulation is an evaluation tools for the designer before deigning and executing the proposed building.

\section{References}

[1] Atwa, Mostafa, 2016 "Architectural Design with Environmental Solutions as a Scope for Sustainability: Achieving Energy Efficiency in Buildings Passively" Journal of Buildings and Sustainability. Available [Online],: http://www.insightcore.com/journal/architectural-design-environmental-solutionsscope-sustainability-atwa-2016.html

[2] Electric Energy Holding Company Ministry of Electricity and Energy

[3] http://www.iea.org/statistics

[4] Ariyasinghe, D.P. and Vilathgamuwa, D.M., 2008" Stability analysis of microgrids with constant power loads," in S u stai n able En ergy Tech n ologi es "2008. ICSET 2008. IEEE International Conference on, 2008, P.p. 279-284.

[5] F. Jaugscha, M.-O. Löwner .2016."Estimation of solar energy on vertical 3D building walls on city quarter scale". International Archives of the Photogrammetry, Remote Sensing and Spatial Information Sciences, Volume XLII-2/W2, 2016 11th 3D Geoinfo Conference, 20-21 October 2016, Athens, Greece.P.p.: 1-9.

[6] Korany, M. et al.,2016 "A data base of multi-vear (2004-2010) quality-assured surface solar hourly irradiation measurements for the Egyptian territory", Earth Syst. Sci. Data, vol. 8, no. 1, P.p. 105-113, 2016.

[7] Researchers

[8] https://ar.climate-data.org/(altitude:78m)

[9] L. T. Shen and J. Fan, 2015 "S tudv on the Perform an ce of Vertical Solar PV S ystem s in Tropical $\boldsymbol{R}$ egion ,"Adv. Energy Eng., vol. 3, pp. 1-7, 2015. 
[10] "Suntech STP250S-20/Wd (250W) Solar Panel." [Online]. Available: http://www.solardesigntool.com/components/module-panelsolar/Suntech/1659/STP250S-20-Wd/specification-data-sheet.html.

[11] D. P. Ariyasinghe and D. M. Vilathgamuwa, 2008 "S tabi li tv an alvsis of $m$ icrogri ds $\underline{w i t h}$

con stant pow er loads ,” in Sustainable Energy Technologies, 2008. ICSET 2008. IEEE International Conference on, 2008, P.p. 279-284.

[12] M. A. Eltawil and Z. Zhao, 2010 "Grid-connected photovoltaic power systems: Technical and potential problems-A review," Renew. Sustain. Energy Rev., vol. 14, no. 1, P.p. 112-129, 2010.

[13] http://www.proinso.net/solar-energy-projects(24/11/2017) 